\title{
BATERAI TES FISIK PEMAIN TENIS MEJA KELOMPOK PEMULA
}

\author{
Hanik Liskustyawati ${ }^{1}$, Sapta Kunta Purnama ${ }^{2}$, Sri Santoso Sabarini ${ }^{3}$, Rony Syaifullah ${ }^{4}$ \\ ${ }^{1234}$ Universitas Sebelas Maret \\ honey_hany86@yahoo.com
}

\begin{abstract}
Abstrak
Terbatasnya jumlah pemain kategori pemula sebagai pelapis pemain kategori kadet dan senior perlu segera diatasi dengan menambah kuantitas calon pemain yang potensial dan sesuai dengan keberadaannya. Pemain kategori pemula diperlukan penyiapan sedini mungkin dengan menggunakan pendekatan ilmu pengetahuan dan teknologi keolahragaan. Penyiapan pemain secara tepat masih banyak kendala yang dihadapi utamanya adalah belum tersedianya baterai tes di cabang tenis meja untuk kategori pemula.

Teknik pengumpulan data menggunakan tes dan pengukuran fisik pemain tenis meja tingkat pemula. Tes dan pengukuran meliputi: a). Tes antropometrik, yaitu: (1) tinggi badan, (2) rentang lengan, (3) panjang tungkai. b). Tes kemampuan fisik, terdiri: (1) Koordinasi mata tangan, (2) Hand reaction test, (3) Kelentukan: flexcion of thrunk, (5 ) sit and reast, (6) kecepatan lari: $20 \mathrm{~m}$, (7) kelincahan: shuttle run, (8) keseimbangan: stok stand test, power otot tungkai: (9) standing broad jumps, (10) vertical power jumps, (11) power otot lengan: lempar bola medicen, (12) kekuatan: sit-up, (13) daya tahan kardiovaskuler: lari $1200 \mathrm{~m}$. Subyek penelitian: peserta tenis meja kategori pemula (usia $10-12$ tahun) yang tercatat sebagai pemain pada klub tenis meja di Kota Surakarta dan telah mengikuti latihan di masingmasing klub sekurangnya 2 tahun.

Hasil penelitian tes dan pengukuran fisik tenis meja kategori pemula dari sejumlah 15 item tes memiliki rata-rata reliabilitas tes tinggi yaitu 0,87 dan validitas tes 0,89 untuk peserta kategori putra. Sedangkan untuk peserta kategori putri diperoleh rata-rata reliabilita tes 0,85 dan validitas tes 0,88 . Baterai tes fisik pemain tenis meja kelompok pemula untuk putra maupun putri urutan tesnya meliputi: Kecepatan reaksi tangan; Tes lempar tangkap bola tenis; Shuttle run; Kecepatan lari 20 m; Lari 1200 m.
\end{abstract}

Keywords: Tes Fisik Pemain Tenis Meja

\section{PENDAHULUAN}

Slogan yang telah dicanangkan sejak orde baru yaitu "memasyarakatkan olahraga dan mengolahragakan masyarakat" yang kemudian terakomodir sebagai sebuah sistem pembinaan olahraga di Indonesia, digambarkan dalam sebuah piramid yang diawali dengan peningkatan kesegaran jasmani dan pembudayaan olahraga di dalam masyarakat sebagai fondasi utama, kemudian pemassalan dan pembinaan olahraga usia dini dilanjutkan pembibitan, pemanduan dan pembinaan olahraga pelajar, yang kemudian berkonsentrasi untuk pembinaan olahraga prestasi secara intensif di daerah, pembinaan intensif ditingkat nasional secara sistematis, berjenjang dan berkelanjutan dan akhirnya diperoleh atlet tingkat elite sebagai performa tertinggi. 


\section{BANGUNAN OLAHRAGA NASIONAL}

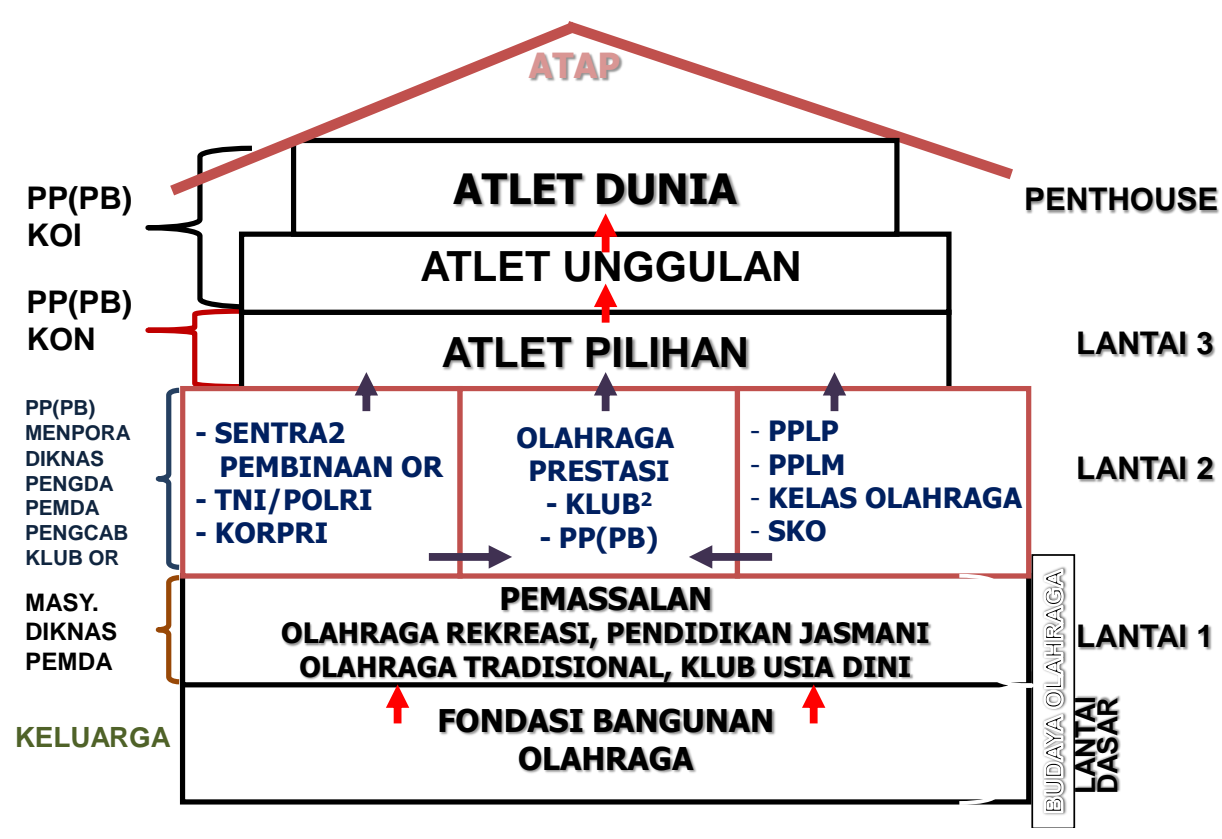

Gambar 1. Bangunan Sistem Pembinaan Olahraga Indonesia

Keberhasilan yang sudah tampak di dalam pembinaan olahraga, apabila dikaitkan dengan langkah pembinaan tersebut adalah pemassalan. Hal itu dapat dilihat dari besarnya persentase penduduk yang gemar berolahraga, sebagai indikator bahwa olahraga telah memasyarakat. Pada tahap yang bersamaan sistem pembinaan usia dini sebagaimana telah diketahui oleh para pembina olahraga di Indonesia, namun kenyataannya sampai sekarang sistem pembinaan, pemanduan dan pengembangan olahraga usia dini yang teratur dan berkesinambungan masih dirasakan mengalami kendala diantaranya adalah: (1) belum adanya system evaluasi yang memadai; (2) keterbatasan waktu, dana dalam usaha peningkatan prestasi olahraga nasional; (3) seringkali pemanduan dilakukan dengan jalan pengamatan atau pengalaman pelatih. Kendala yang ke tiga dengan cara pendekatan tersebut sebagai bagian jalan pemecahan tidaklah salah, namun belum memiliki tingkat keakuratan yang memadai dan belum standar. Dalam Peraturan Presiden Republik Indonesia no. 22 tahun 2010 tersirat bahwa sasaran pengembangan calon atlet andalan nasional adalah atlet potensial yang secara ilmiah maupun faktual memiliki prospek untuk dikembangkan hingga mencapai prestasi tingkat internasional melalui pembinaan berjenjang dan berkelanjutan, yang didasarkan pada prinsip pembinaan atlet jangka panjang. Menurut Doug MacCurdy (2011) mengatakan bahwa "identifikasi olahraga dapat didefinisikan sebagai prediksi kinerja masa depan anaka-anak atau identifikasi pemain muda yang akan mencapai keberhasilan di tingkat 
nasional. Kementerian Pemuda dan Olahraga Republik Indonesia telah melaksanakan sistem pemanduan dan pengembangan olahraga dengan memodifikasi sport search namun sampai sekarang hasilnya kurang memuaskan karena data yang telah mewakili provinsi di seluruh Indonesia belum termanfaatkan secara maksimal.

Pengidentifikasian olahraga pada seluruh cabang olahraga di Indonesia termasuk diantaranya cabang tenis meja belum mempunyai sistem monitoring dan evaluasi yang baik. Standar minimal yang berhubungan dengan sistem seleksi atlet muda belum tersusun secara baku. Upaya untuk meraih prestasi perlu perencanaan yang sistematis, dilaksanakan secara bertahap dan berkesinambungan mulai dari pemasalan, pembibitan hingga mencapai puncak prestasi. Agar diperoleh bibit olahragawan yang baik perlu disiapkan sejak awal yakni dengan program pemasalan yang dilakukan dengan cara menggerakkan anak-anak usia dini untuk melakukan aktifitas olahraga secara menyeluruh atau jenis olahraganya.

Setiap anak pasti dibekali dengan bakat atau talent sebagai potensi yang dibawa sejak lahir, merupakan pembawaan yang diperoleh secara genetik dari faktor keturunan. Bompa (1986: 330) mengidentifikasi sifat anak cenderung mewarisi orang tuanya baik secara psikologis maupun biologis. Namun indikator tersebut belumlah cukup, oleh karena tuntutan untuk dapat melakukan berbagai cabang olahraga sangat beragam. Maka kriteria untuk mengidentifikasi calon olahragawan ber setiap cabang olahraga juga beragam atau multiindikator.Indikasi keberan olahragawan harus dilakukan dengan pengukuran yang obyektif, terhadap beberapa indikator yang diyakini sebagai modal utama yang harus dimiliki calon olahragawan sesuai cabang olahraganya. Kriteria umum dalam pemilihan bibit unggul dikemukakan oleh Menpora (1992: 19) sebagai berikut: memiliki kelebihan kualitas fisik dan mental yang dibawa sejak lahir, memiliki fisik dan mental yang sehat, tidak cacat tubuh, diharapkan postur tubuh sesuai dengan cabang olahraga yang diminati, memiliki fungsi organ tubuh yang baik, seperti jantung, paru-paru, otot, dan saraf, memiliki kemampuan gerak dasar yang baik, seperti kekuatan, kecepatan, daya tahan, koordinasi, kelincahan, dan power, memiliki inteligensi tinggi, memiliki watak kompetitif, berkemauan keras, tabah, pemberani, dan semangat tinggi, gemar melakukan berbagai kegiatan olahraga. Disisi lain Bompa (1990:334) mengemukakan untuk menyeleksi atlet menggunakan pendekatan: (1) natural atau lamiah. Seleksi pendekatan natural atau alamiah pada anak usia dini dengan cara menekuni salah satu cabang olahraga tanpa melalui pengidentifikasian bakat. Anak usia dini menekuni olahraga sebagai akibat dari pengaruh lingkungan, seperti pengaruh teman sebaya, keinginan orang tua, kebiasaan olahraga di sekolah. Perkembangan dan kemajuan atlet sangat lambat, karena tidak adanya pengidentifikasiaan bakat untuk menentukan cabang olahraga yang paling tepat untuk atlet. (2) Seleksi menggunakan pendekatan ilmiah, bahwa dalam proses pengidentifikasian bakat anak usia dini telah menggunakan langkah-langkah berdasarkan pada ilmu pengetahuan dan teknologi. Melalui pendekatan dengan metode ilmiah anak-anak usia dini di tes kemudian diidentifikasi untuk dapat diarahkan ke cabang olahraga yang sesuai dengan potensi dan bakatnya. Lebih lanjut dijelaskan Bompa (2004: 328) ada beberapa 
keuntungan yang diperoleh apabila menggunakan metode ilmiah dalam proses pengidentifikasian bakat, yaitu (1) Mempersingkat waktu yang diperlukan untuk mencapai prestasi optimal. (2) Efisiensi program latihan dapat dicapai bagi atlet yang memiliki potensi dan kemampuan tinggi. (3) Meningkatkan kompetisi, daya saing dan menambah banyaknya jumlah atlet yang berpotensi dan mampu mencapai prestasi tinggi. (4) Meningkatkan rasa percaya diri atlet. (5) Secara tidak langsung tersedia fasilitas untuk penerapan latihan ilmiah.

Melalui seleksi ilmiah calon atlet dapat dipreksi dan diarahkan pada cabang olahraga tertentu. Sistem seleksi atlet merupakan awal dari perencanaan pembinaan dan pada tahapan ini penting untuk menjamin tercapainya prestasi berkelanjutan. Dalam suatu sistem seleksi terdapat tahapan seleksi dan penetapan calon atlet yang memenuhi persyaratan tes serta kriteria tertentu. Seleksi olahraga cabang tenis meja yang diterapkan lebih sering mengandalkan pada pendekatan pengamatan dan pengalaman pelatih. Sistem pemanduan dengan melakukan tes tenis meja perlu dilakukan sehingga dapat dipakai sebagai pedoman. Beberapa klub tenis meja di Jawa Tengah hanya sebagian kecil yang menerapkan sistem seleksi calon atlet dengan melaksanakan tes fisik, tes dan pengukuran biomotorik sehingga belum teruji efektivitasnya sebagai parameter keberhasilan. Berdasarkan pelaksanaan seleksi pemanduan bakat tenis meja, terdapat elemen tes seleksi calon atlet yang kurang sesuai dengan prinsip bentuk tes, diantaranya: (1) subtansi tes secara teoritis kurang sesuai dengan kriteria atlet tenis meja; (2) validitas tes belum teruji. Sebagai indikator kurang validnya instrumen yang dipakai sebagai elemen tes yaitu: lari jarak menengah dengan 7 kali putaran lintasan dan lari multistage Fitness Test.

Banyak jenis tes keterampilan dan kemampuan fisik yang digunakan untuk keperluan seleksi calon atlet maupun atlet tenis meja, namun belum diuji seberapa besar efektifitasnya terhadap penampilan tenis meja. Pemilihan elemen tes tenis meja didasari oleh logika dan kebutuhan kemampuan fisik yang belum diuji secara empirik. Menurut Allen Philips (1979: 1-2) Tes biasanya diartikan sebagai alat atau instrumen dari pengukuran yang digunakan untuk memperoleh data tentang suatu karakteristik atau ciri yang spesifik dari individu atau kelompok. Tes tersebut seharusnya relevan dengan karakteristik yang akan dites, reliabel dan spesifik sebagai alat ukur baik secara individu maupun kelompok. Sehingga tingkat validitas suatu tes menunjukkan kepada pengguna tes bahwa tingkatan validitas tersebut mampu mencapai tujuan tertentu.

Elemen tes berdasarkan beberapa kajian dari para ahli tentang tes keterampilan tenis meja rancangan tesnya meliputi: servis, push, forehand drive, counter test (Pushpendra Purashwani dan A.K. Datta: 2010). Rancangan tes berdasarkan kajian dari elemen tes fisik tenis meja, antara lain: Treadmill running test, lactate minimum test, cranking ergometer, cycle ergometer (Miran Kondrič 1, Alessandro Moura Zagatto 2 and Damir Sekulić 3: 2013). Rancangan tes fisik sebagaimana pendapat pakar tersebut sangat sulit untuk dilakukan dimasing-masing klub apalagi di daerah. Berdasarkan elemen fisik hasil konsultasi dengan pelatih tenis meja Jawa Tengah antara lain : 


\section{RUMUSAN MASALAH}

Sejalan dengan latar belakang masalah maka rumusan masalah dalam penelitian ini adalah:

1. Bagaimana baterai tes fisik pada pemain putra kategori pemula pada cabang tenis meja?

2. Bagaimana baterai tes fisik pada pemain putri kategori pemula pada cabang tenis meja?

\section{PEMBAHASAN}

Sistem pembinaan seperti dalam gambar 1 menyediakan kesempatan yang seluasluasnya bagi semua anak dan remaja untuk berpartisipasi dalam kegiatan olahraga sebagai bekal untuk mencapai prestasi. Banyak factor yang dapat mempengaruhi prestasi tenis meja, sebagaimana dikemukakan Nossek (1982: 12) bahwa prestasi olahraga bergantung pada unsur-unsur, antara lain: (1) keterampilan dan teknik yang diperlukan, dikembangkan, dikuasai dan diotomatisasikan; (2) kemampuan-kemampuan yang didasarkan pada pengaturan latihan kebugaran tubuh, kemampuan gerak, kemampuan belajar koordinasi; (3) perilaku yang baik untuk menghadapi situasi dalam kompetisi; (4) pengembangan taktik dan strategi; (5) kualitas perilaku afektif, kognitif dan sosial.

Mencapai prestasi tinggi diperlukan latihan yang dapat mengembangkan kondisi fisik, teknik, taktik dan psikis, didukung bakat pemain, tersedia sarana dan prasarana serta kompetisi yang baik. Pesurney (2005: 7) mengemukakan bahwa peningkatan kemampuan fisik ditentukn oleh latihan yang terarah, disamping itu usia pemain, bakat, sifat organ tubuh, ukuran otot, tingkat pengendalian koordinasi dan kemampuan psikis.

\section{a. Tes Fisik}

Tes fisik merupakan kajian tentang daya fisik yang mewujudkan gerakan tubuh sedangkan domain psikomotorik mengkaji terhadap gerakan-gerakan tubuh. Pentingnya kualitas fisik di dalam menunjang keterampilan gerak di dalam keolahragaan, maka domain fisik memperoleh porsi penanganan secara khusus. Antara domain fisik dan domain psikomotorik tidak bisa dipisahkan, melainkan hanya bisa dibedakan. Fungsi fisik dan fungsi psikomotorik di dalam berlatih olahraga harus beda membedakan mana yang lebih diutamakan untuk ditingkatkan pada periode latihan tertentu. Pada tahap tertentu diutamakan latihan penguasaan gerak, pada tahap yang lain perlu diutamakan latihan peningkatan kualitas fisik.

Pengertian domain fisik pada penelitian ini adalah komponen kebugaran atau fitness yang diperlukan pemain sesuai dengan cabang olahraga dan perannya. Fisik merupakan fondasi dari bangunan prestasi hal ini dikarenakan factor teknik, taktik,psikis dapat dikembangkan dengan baik apabila pemain memiliki bekal kualitas kualitas fisik yang baik. Di dalam materi pelatihan kondisi fisik (2009: 15) disebutkan bahwa kemampuan biomotor 
dasar meliputi lima jenis, yaitu: kekuatan, daya tahan, kecepatan, fleksibilitas dan koordinasi. Elemen-elemen kemampuan tersebut mempunyai peran masing-masing dari suatu cabang olahraga, dengan kata lain kemampuan fisik bagi calon pemain dari berbagai cabang olahraga adalah syarat untuk menampilkan kinerja dengan kualitas tertentu. Dalam kaitannya dengan pencapaian prestasi olahraga di masa yang akan datang, fenomena tersebut dapat dianalisis agar proses pengembangan prestasi olahraga lebih efektif dan efisien.

Inovasi pemikiran dari kajian terori yang ada adalah melakukan seleksi berdasarkan fakta hasil observasi dan factor-faktor determinan utama dari prestasi tenis meja yang berkaitan dengan domain fisik, meliputi: a). Karakteristik antropometrik, yaitu: (1) tinggi badan, (3) rentang lengan, (4) panjang tungkai. b) Karakteristik kemampuan fisik, terdiri: (1) Koordinasi mata tangan, (2) Hand reaction test, (3) Kelentukan: flexcion of thrunk, sit and reast, kelentukan pergelangan tangan, (4) kecepatan lari: $20 \mathrm{~m}$, (5) kelincahan: shuttle run, (6) keseimbangan: hexagonal obstacle test, (7) power otot tungkai: standing broad jumps, vertical power jumps, (8) power otot lengan: lempar bola medicen, (9) kekuatan: sit-up, (11) daya tahan kardiovaskuler: multidstage fitnees test (MFT).

\section{b. Instrumen}

Salah satu fase terpenting dalam program pengukuran dan evaluasi adalah menseleksi dan mengkonstruksi instrumen atau tes. Menurut Riduwan ( 2006: 37) tes sebagai instrumen pengumpulan data adalah serangkaian pertanyaan/latihan yang digunakan untuk mengukur keterampilan pengetahuan, intelegensi, kemampuan atau bakat yang dimiliki individu/kelompok. Dalam mengkontruksi instrument yang perlu diperhatikan interprestasi skor yang dihasilkan harus tepat, bermanfaat, dan dapat digunakan pada keadaan tersebut.

Semua jenis instrumen diatas agar memiliki kemampuan mengevaluasi karakteristik penting tertentu. Untuk mendukung penelitian pendahuluan ini mengutip beberapa teori ilmiah yang berkaitan dengan tes pengukuran dan evaluasi, fisiologi olahraga. Sebuah tes dapat digunakan apabila memiliki tingkat validitas, reliabilitas dan obyektivitas yang tinggi.

Menurut Verducci (1980: 145-163) karakteristik esensial seleksi dan pengembangan instrument dalam pendidikan jasmani adalah: (1) Validitasi, (2) reliabilitas, (3) obyektivitas, dan (4) administrabilitas. Sejalan dengan pendapat tersebut, menurut Sukardi (2010: 29) adalah: (1) valid, (2) reliable, dan (3) dapat digunakan (usability). Selanjutnya di dalam pedoman pemanduan bakat olahraga (1998: 23-25) disebutkan halhal yang perlu diperhatikan dalam pengembangan tes, yaitu: (1) validitas, (2) relibiltas, (3) daya pembeda, (4) umur, (5) aplikabilitas, dan (6) kemudahan administrasi tes.

\section{c. Validitas}

Validitas adalah tingkat ketepatan penggunaan alat dengan apa yang seharusnya 
diukur. Validitas suatu instrument adalah derajat yang menunjukkan di mana suatu tes mengukur apa yang hendak diukur. Suatu tes atau instrument pengukuran adalah valid apabila ia mengukur apa yang seharusnya diukur. Sebagai contoh, tes lari $40 \mathrm{~m}$ adalah valid untuk mengukur kecepatan lari, namun tidak valid untuk mengukur fleksibilitas.

\section{d. Reliabilitas}

Reliabilitas dapat diartikan sebagai konsistensi hasil pengukuran apabila dilakukan beberapa kali pada individu yang sama pada kondisi yang sama. Jadi reabilitas dapt diartikan sama dengan konsistensi. Suatu instrument dikatakan reabilitas apabila tes yang dibuat mempunyai konsistensi yang tinggi dalam mengukur yang hendak diukur. Derajat reliabilitas dinyatakan oleh koefisien korelasi dengan rentangan dari 0,00 sampai 1,00, semakin besar skor berarti semakin reliable.

\section{e. Obyektivitas.}

Obyektivitas dapat didefinisikan sebagai persetujuan dari dua atau lebih penilai yang kompeten tentang skor suatu pengukuran.obyektivitas dapat juga diistilahkan sebagai sebagai reliabilitas antar penilai (rater reliability). Apabila dua orang penilai atau pemberi angka member skor seorang individu dengan tes yang sama dan tiak sependapat dengan skor yang diberikan, maka tes tersebut tidak cukup obyektivitasnya.

\section{f. Administrabilitas.}

Administrabilitas berkaitan dengan pertimbangan praktis dalam memilih instrument tes. Aspek ini adalah merupakan aspek penting dari criteria tes baik selama itu tidak berpengaruh negatif pada criteria lain. factor untuk pertimbangan dalam menentukan ketergunaan instrument antara lain: (1) kemudahan administrasi tes, (2) waktu yang diperlukan, (3) urutan tes, (4) ketersediaan fasilitas dan perelatan, dan (5) biaya.

Kemudahan administrasi tes diartikan adanya petunjuk pelaksanaan yang lengkap akan memberikan tuntunan bagi petugas tes maupun testinya, sehingga mudah dalam melakukannya waktu yang diperlukan erat hubungannya dengan besarnya biaya. Demikian pula sarana dan prasarana yang dipakai dalam pelaksanaan tes, makin sedikit alatalat personil dalam pelaksanaan tes tersebut, makin sedikit biaya yang dikeluarkan. Selain kriteria tersebut, ketersediaan norma dalam suatu tes juga sangat penting, adanya norma mempermudah membandingkan nilai yang dicapai subyek dalam suatu tes. 


\section{HASIL DAN SIMPULAN}

Tabel 1. Hasil Validitas dan Reliabilitas Tes tenis Meja Domain Fisik

\begin{tabular}{|lcccc|}
\hline No. Test & Validity & \multicolumn{3}{c}{ Reliability } \\
\hline High & 0.91 & 0.90 & 0.92 & 0.91 \\
Range of hand & 0.92 & 0.86 & 0,91 & 0.88 \\
Length of leg & 0.90 & 0.92 & 0,91 & 0.94 \\
Coordination & 0.93 & 0.91 & 0,94 & 0.92 \\
Hand reaction test & 0.90 & 0.89 & 0.91 & 0.90 \\
Flexion of trunk & 0.75 & 0.67 & 0.75 & 0.66 \\
Sit and reach & 0.93 & 0.92 & 0.94 & 0.93 \\
Wrist flexibility & 0.70 & 0.93 & 0.71 & 0.94 \\
Run 20 m & 0.91 & 0.76 & 0.91 & 0.77 \\
Shuttle run & 0.74 & 0.77 & 0.95 & 0.79 \\
Standing broad jumps & 0.69 & 0.70 & 0.68 & 0.71 \\
Vertical power jumps & 0.83 & 0.69 & 0.83 & 0.71 \\
Throwing a ball medicine & 0.76 & 0.72 & 0.79 & 0.73 \\
Sit-up & 0.65 & 0.67 & 0.66 & 0.66 \\
Run 1200 m & 0.91 & 0.89 & 0.92 & 0.91 \\
\hline
\end{tabular}

Tabel 2. Baterai Tes Fisik Tenis Meja Untuk Pemain Pemula Putra Dan Putri

\begin{tabular}{|l|l|}
\hline \multicolumn{1}{|c|}{ Baterai Tes Putri } & \multicolumn{1}{c|}{ Baterai Tes Putra } \\
\hline 1. Kecepatan reaksi tangan: & 1. Kecepatan reaksi tangan \\
2. Tes lempar tangkap bola tenis & 2. Tes lempar tangkap bola tenis \\
3. Shuttle run & 3. Shuttle run \\
4. Kecepatan lari $20 \mathrm{~m}$ & 4. Kecepatan lari $20 \mathrm{~m}$ \\
5. Lari $1200 \mathrm{~m}$ & 5. Lari $1200 \mathrm{~m}$ \\
\hline
\end{tabular}




\section{Simpulan:}

1. tes dan pengukuran fisik tenis meja kategori pemula dari sejumlah 15 item tes memiliki rata-rata reliabilitas tes tinggi yaitu 0,87 dan validitas tes 0,89 untuk peserta kategori putra. Sedangkan untuk peserta kategori putri diperoleh rata-rata reliabilita tes 0,85 dan validitas tes 0,88 . validitas keduanya termasuk sangat baik dan memiliki daya pembeda yang signifikan pada taraf $(\mathrm{p}=0.05)$.

2. Bentuk instrumen tes fisik bagi pemain tenis meja yang dikemukakan beberapa pakar keolahragaan tersirat adanya fenomena bahwa pemain tenis meja harus diketahui domain fisiknya secara akurat. Kaitannya dengan pencapaian prestasi olahraga dimasa yang akan datang, fenomena tersebut dapat dianalisis agar proses pengembangan prestasi lebih efektif dan efisien. Permainan tenis meja yang lebih banyak menggunakan keterampilan tangan dalam hal teknik pukulan sehingga memerlukan domain fisik yang baik.

3. Terdapat dua rangkaian tes fisik tenis meja umur 10-12 tahun, mempunyai implikasi pada upaya sistem seleksi dan pembinaan prestasi tenis meja, upaya tersebut akan lebih efisien dengan pendekatan ilmiah, salah satunya dengan menggunakan tes dan pengukuran lapangan untuk pemain tenis meja karena secara statistik akan memberi pengaruh dalam keberhasilan pembinaan dan lebih baik dibanding dengan tidak menggunakan tes. Hasil penelitian menyimpulkan bahwa rangkaian tes fisik antara pemain putra dan putri tidak berbeda. Hal ini mengindikasikan bahwa untuk mengidentifikasi pretasi tenis meja faktor-faktor yang berpengaruh secara dominan merupakan pilihan yang tepat untuk dilaksanakan. Seorang pemain tenis meja membutuhkan kualitas kemampuan fisik, yaitu:

a. Kecepatan reaksi tangan Permainan tenis meja membutuhkan tempo permainan yang cepat, untuk menerima dan mengembalikan bola seorang pemain tenis meja membutuhkan kecepatan reaksi yang tinggi, dan sebaliknya jika seorang pemain memiliki kecepatan reaksi yang rendah maka akan terlambat dalam menjangkau bola yang datang sehingga mengalami kesulitan saat menerima dan mengembalikan bola kearah lawan. Kecepatan reaksi tangan seorang pemain tenis meja merupakan cerminan penguasan teknik khusus sehingga mengindikasikan bahwa keterampilan dalam tenis meja memerlukan kualitas kemampuan yang spesifik.

b. Koordinasi gerak yang baik, hal ini berdampak pada kemampuan untuk memberikan respon terhadap datangnya bola yang arah dan geraknya tidak terduga melalui gerak memanipulasi bet (gerak memukul) untuk mengembalikan bola ke meja lawan yang arah dan geraknya dapat mematikan permainan lawan. Selain hal tersebut dalam permainan tenis meja, koordinasi mata tangan mempunyai peranan yang besar karena pada waktu akan memukul bola, hal pertama yang perlu dilakukan pemain untuk mengantisipasi bola yaitu melihat gerakan lawan, membaca arah datangnya bola, selanjutnya menentukan jarak yang tepat untuk mengayunkan bet. Koordinasi mata tangan yang baik tentunya akan sangat membantu dalam permainan tenis meja, 
sehingga pemain tidak akan kesulitan untuk memukul, dan mengembalikan bola dari lawan.

c. Kelincahan gerak ke samping kanan, kiri, ke depan, belakang sangat diperlukan dalam pencapaian prestasi tenis meja, kemampuan menempatkan diri secepat mungkin untuk dapat dekat dengan posisi bola akan memudahkan pemain dalam memainkan bet sehingga memudahkan untuk mengarahkan bola ke lapangan lawan, sebelum lawan sempat menempatkan posisi yang menguntungkan. Daya tahan kardiorespirasi $\left(\mathrm{VO}_{2}\right.$ maks) yang memadai untuk beraktifitas pada intensitas yang waktunya relatif lama, apabila kemampuan kondisi tersebut tidak memadai maka memberi dampak pada buruknya pencapaian prestasi.

\section{DAFTAR PUSTAKA}

Bompa, Tudor O., G. Gregory Haff. (2004). Periodization Theory and Methodology of Training, New York: Kendall/Hunt Publising Company.

Miran Kondrič , Alessandro Moura Zagatto, Damir Sekulić. (2013). The physiological Demands of Table Tennis. International Journal of Table Tennis Sciences. Volume 4. No. 10

Verducci, F.M. (1980).Measurement Concepts In Physical Education. United States of America: The C.V. Mosby Company.

Pesurney, Paulus. (2005). Hight Theory Performance Training. Bogor: Workshop bagi pelatih PAL, Gunung Geulius.

Pushpendra Purashwani, A.K. Datta, Manoj Purashwani. (2010). Construction of Norms for Skill Test Table Tennis Players. International Journal of Table Tennis Sciences, Vol 10, No.6

Sukardi, (2010) Pedoman Pemanduan Bakat Olahraga, Jakarta: Kemenpora.

Riduwan ( 2006) Materi pelatihan kondisi fisik

Nossek, Josef. (1982) General Theory of Training. Logos: National for Sports. 1982: 12 